\title{
The implication of deprivation of freedom on fathering: a qualitative study
}

\section{A implicação da privação de liberdade no exercício da paternidade: um estudo qualitativo}

\section{La implicación de la privación de libertad en la paternidad: un estudio cualitativo}

\author{
Sabrina Daiana Cúnico ${ }^{1}$, ORCID 0000-0003-2198-9957 \\ Marlene Neves Strey ${ }^{2}$, ORCID 0000-0003-3030-5668 \\ Ângelo Brandelli Costa ${ }^{3}$, ORCID 0000-0002-0742-8152 \\ ${ }^{1}$ Universidade Feevale. Brasil \\ ${ }^{23}$ Pontificia Universidad Católica de Río Grande del Sur (PUCRS). Brasil
}

\begin{abstract}
This study aims to analyze fathering practices and the meanings attributed to it by imprisoned men. Semi-structured interviews were conducted with twelve fathers, incarcerated in a penal institution located in in southern Brazil. Transcribed data were analyzed through the Critical Discourse Analysis. Results are presented according to two themes: Deprivation of freedom X Deprivation of Fatherhood and Criminality X Fatherhood. Our findings indicate that the meanings attributed to fathering practices within deprivation of freedom context rely on different psychosocial factors and the prison context itself. The results presented here demonstrate that paternity in prison is a complex phenomenon and should be a focus of academic problematization. Its relevance is given both in the context of gender studies and in the studies involving the family and different settings.
\end{abstract}

Keywords: Fathering, Gender, Prison, Incarceration

Resumo: Este estudo tem como objetivo analisar as práticas parentais e os significados atribuídos a elas por homens encarcerados. Foram realizadas entrevistas semiestruturadas com doze pais, encarcerados em uma instituição penal localizada em sul do Brasil. Os dados transcritos foram analisados por meio da Análise Crítica do Discurso. Os resultados são apresentados de acordo com duas categorias: Privação de liberdade X Privação de paternidade e Criminalidade X Paternidade. Os resultados indicam que os significados atribuídos às práticas parentais no contexto da privação de liberdade se baseiam em diversos fatores psicossociais e o próprio contexto prisional. Os resultados aqui apresentados demonstram que a paternidade na prisão é um fenômeno complexo e deve ser foco de problematização acadêmica. Sua relevância é dada tanto no contexto dos estudos de gênero quanto nos estudos que envolvem a família e diferentes contextos.

Palavras-chave: Paternidade, Gênero, Prisão, Encarceramento 
Resumen: Este estudio tiene como objetivo analizar las prácticas de paternidad y los significados que le atribuyen los hombres encarcelados. Se realizaron entrevistas semiestructuradas con doce padres, encarcelados en una institución penal ubicada en el sur de Brasil. Los datos transcritos fueron analizados a través del Análisis Crítico del Discurso. Los resultados se presentan de acuerdo con dos temas: Privación de libertad X Privación de paternidad y Criminalidad X Paternidad. Nuestros hallazgos indican que los significados atribuidos a las prácticas paternales en el contexto de privación de libertad se basan en diversos factores psicosociales y el contexto carcelario en sí. Los resultados presentados aquí demuestran que la paternidad en la prisión es un fenómeno complejo y debe ser un foco de problematización académica. Su relevancia se da tanto en el contexto de los estudios de género como en los estudios que involucran a la familia y diferentes entornos.

Palabras clave: Paternidad, Género, Prisión, Encarcelamiento

Received: $11 / 19 / 2018$

Accepted: 05/12/2020

How to cite this article:

Cúnico, S.D., Strey, M.N., \& Costa, A.B. (2020). The implication of deprivation of freedom on fathering: a qualitative study. Ciencias Psicológicas, 14(1), e-2192. doi: https://doi.org/10.22235/cp.v14i1.2192

Correspondence: Sabrina Daiana Cúnico. Universidade Feevale. Brasil.Email: sabrinacunico@yahoo.com.br

\section{Introduction}

When we examine the prison environment, the experience of deprivation of freedom transforms relationships at all levels, the father-child relationship being no exception. Deprivation of freedom happens through confinement in an institution, cut off from family and kin. With the penalty of imprisonment, the individual loses, in addition to his freedom, his autonomy and finds himself inserted in an environment in which disciplinary practices seek to nullify his wishes and personal desires (Fonseca, 2006).

However, despite the high number of imprisoned men who are fathers (Mapson, 2013), fathering is rarely examined in a prison context. The opposite happens to motherhood, an experience that is discussed more often. Usually, the studies on maternity in prison seek to understand the impact of female incarceration on the experience of being a mother (Lee, Sansone, Swanson, \& Tatum, 2012; Miranda \& Granato, 2016; Techera, Garibotto, \& Urreta, 2012). This fact shows that in prison, too, maternity is seen as more relevant than paternity. This is probably because culturally, motherhood is still seen as central to the identity of women, and it is no different with those mothers who are in prison.

A systematic review of the literature on fatherhood in the prison context did not identify any Brazilian study (Cúnico, Quaini \& Stey, 2017). This situation contrasts with the alarming numbers of the male population in prison. According to official data, in 2016, Brazil had more than 700.000 incarcerated people. By 2014, the number was about 620.000 , with an increase of almost 100.000 people incarcerated over two years. These numbers make the country 3rd place in the ranking of countries with the largest contingent of persons deprived of their freedom, behind only the United States and China (Brasil, 2017). In addition to the significant number of prisoners, the prison system in the country is marked by the poor conditions of prison institutions, such as overcrowding, the division of prisoners into criminal factions, and structural precariousness (Tavares \& Menandro, 2004). 
Even if it is admitted that there is a movement that is strengthened today - from questioning old values and opening to new ways of experiencing the role of the fatherhood -, it is still frequent to exclusively link paternity with the function of financial provision, as if the care function was secondary or a choice of men (Bornholdt, Wagner \& Staudt, 2007). Thus, those parents who are serving a custodial sentence may be seen as having little value for their children, as they do not constitute themselves as providers during incarceration. In this way, the maintenance of contact between father and son can be underestimated, which may partly justify the scarcity of studies addressing these aspects.

Social-demographic data reveals that the Brazilian prison population is composed, of a majority of young (between 18 and 29 years old) black men who have not completed primary education ( $1^{\text {st }}$ to $8^{\text {th }}$ grade in Brazil) and come from lower social strata (Brasil, 2017). To avoid essentialist or reductionist interpretations of this population, inquiries about fathering within the prison context must consider the intersection of gender, race, and other class markers (Andersen \& Collins, 2007).

Concerning fathering practices within the prison context, concerns are mainly raised around the idea that children of male inmates might follow their steps towards criminality (Ugerlvik, 2014), in contrast to research around motherhood within the prison context, in which themes such as affection and relationship between female inmates and their children are more thoroughly explored. Due to the limited research on the topic, our study focuses on a particular dimension implied in the deprivation of freedom: the bond established between the incarcerated father and his offspring.

According to the Law of Penal Executions (LEP), responsible for regulating the execution of sentences of convicted criminals in Brazil, the incarcerated individual is granted the right to receive visits at the prison where he is serving his sentence, to maintain contact with his family (Brasil, 1984). In addition to the LEP, another Brazilian law (no. 12,962, enacted in April 2014) amends the Child and Adolescent Statute (ECA) ensuring that children and adolescents whose parents are imprisoned continue to have contact with the incarcerated parent. Paragraph 4 guarantees "a relationship between child and adolescent with the mother or father deprived of freedom, using periodic visits promoted by the responsible tutor or, in case of institutionalization, by the responsible entity, regardless of judicial authorization" (Brasil, 2014).

However, while the legislation protects the prisoner's right to maintain emotional ties during the period in which they are deprived of freedom, and also stipulates the child's right to maintain contact with the incarcerated parent, the prison structure often fails to provide the means for contact to occur. In fact, due to the precarious situation of overcrowded prisons, many psychosocial programs and visitation incentive initiatives end up obliterated by the priority given to safety and disciplinary issues (Hairston, 2003; Silva \& Guzzo, 2007; Techera, Garibotto, \& Urreta, 2012). The Brazilian penal system does not necessarily guarantee privacy for its inmates, and family visitations often take place inside prison galleries or cells. Because of this, sustaining visitations can be challenging, inevitably changing relationships (Jarvis, Graham, Hamilton, \& Tyler, 2004; Silva \& Guzzo, 2007).

Considering the aspects here presented, this study aims to expand the focus on the meanings attributed to fathering to a context that does not necessarily fit into the centrality of being a father within the masculine identity and the traditional family models, such as a nuclear family. Our objective is, therefore, to analyze fathering practices and the meanings attributed to it by imprisoned men.

\section{Method}

\section{Context}

This study was conducted in a correctional facility in the state of Rio Grande do Sul, southern Brazil. This institution has the capacity for 1,905 inmates. However, it houses more than 4,300 according to official data. That means that it is an overcrowded institution in a precarious state of conservation. This facility was chosen due to it holding the highest number of prisoners in the state and there being an expressive number of visits. Many of these are sons and daughters who continue to maintain contact with 
their imprisoned father. In 2017, for instance, more than 230,000 visits occurred in this facility. $88 \%$ of those were women, most of them mothers and partners of the inmates. Sons e daughters and stepchildren represented about $7.5 \%$ of all visits, which represents more than 18,000 entrances. Their age varied from 0 to 17 years old, but $83 \%$ aged from 0 to 10 years old (Susepe, 2017). It is worth noting that the visits occur inside the cells and galleries, without any supervision of the guards, due to the precarious conditions of this facility.

\section{Participants}

This study was conducted with the participation of twelve fathers serving closed regime sentences in one correctional facility. Participants were between 22 and 60 years old, three of them were married, three of them were in a stable union (a relationship where people are living as if married but without having a civil marriage) and six were single. Regarding race, eight of them self-declared white, two self-declared black, and two self-identified as brown. Only four of the interviewees had completed primary education, seven had not completed primary education, and one declared to be only literate.

These men are serving time for crimes of drug trafficking, robbery, robbery with extortion, illegal possession of firearms, and rape. Information regarding the familial characterization of participants is presented in Table 1.

Table 1

Characteristics of participants

\begin{tabular}{llll}
\hline Participant identification & Age & Marital status & Race \\
\hline Márcio & 60 years old & Married & White \\
Leonardo & 35 years old & Stable Union & White \\
Diego & 48 years old & Married & White \\
Miguel & 40 years old & Married & White \\
Daniel & 34 years old & Stable Union & White \\
Lucas & 24 years old & Single & Mixed \\
Eduardo & 22 years old & Single & White \\
João & 51 years old & Stable Union & Black \\
Fernando & 34 years old & Single & White \\
Thomas & 27 years old & Single & Black \\
Pedro & 25 years old & Single & Mixed \\
Sérgio & 33 years old & Single & White \\
\hline
\end{tabular}

\section{Instruments and procedures}

The selection of the interviewees started by informing the sector responsible for guiding researches in the correctional facility about the inclusion criteria, which was only being a father and having been deprived of freedom for at least six months. Based on these criteria, the administration asked an officer who has direct contact with the prisoners to extend the invitations to participating in this research.

Participation included answering a semi-structured interview, which was conducted by the first author. The interviews were conducted in a room in the prison's administrative building. The semistructured interview as a method was chosen as an information-gathering tool, once it is considered an appropriate method to capture and interpret reality from the viewpoint of the social actors (Poupart, 2008). The idea was to give voice to the imprisoned men, rather than seeking to unveil "the truth" about their 
stories. As Cisneros-Puebla, Faux and Mey (2004) point out "the interview gives individuals appropriate outlets through which their experiences and thoughts can be shared with others in meaningful interactions" (p. 2). All interviews were recorded on audio and transcribed for further analysis.

This research was approved by the School of Penitentiary Service and by the Research Ethics Committee of the institution where the researchers are affiliated, under the number CAEE: 47039315.4.0000.5336.

\section{Data analysis}

Analysis of the transcribed material was carried out using the Critical Discourse Analysis. By definition, this analysis seeks not only to describe discourse structures, but also to focus on how these structures produce, confirm, legitimize, reproduce, or challenge existing power and domination relationships in society (Van Dijk, 2008).

The discourses of this research participants were, therefore, contextualized and analyzed according to two levels of social determination: micro and macro. At the micro-level, we sought to identify in which ways fathers signify and practice fathering while being incarcerated. The micro-level also concerns the context of the actual interview - the relationship with a female researcher, the fact that they are in an institution of deprivation of freedom, as well as their distrust and assumption that their words could somehow impact their sentences. At the macro level, the analysis focused on the institutional and social contexts that shape the discourse delivered by these men during an interview setting.

\section{Results and Discussion}

The results will be shown by two categories of analysis: Deprivation of freedom X Deprivation of fatherhood and Criminality X Fatherhood. The illustrative statements will be presented under fictitious names assigned to the participants to safeguard their anonymity.

\section{Deprivation of freedom X Deprivation of fatherhood}

In this category, the particularities of the exercise of fatherhood in the context of deprivation of freedom are discussed, as well as the similarities and differences, in the view of incarcerated fathers, of the fatherhood lived outside and inside the prison facility.

Several imprisoned men have children from different relationships, taking on different roles with each of them (Mapson, 2013, Ugerlvik, 2014). It is not unusual for the same men to define himself as a present and involved father in the life of one of his children, and absent in the life of another, indicating that fathering is not static or unique. On the contrary, fathering can be fluid and somewhat ambiguous experience (Machado \& Granja, 2013).

Serving in a closed regime sentence in a correctional facility invariably defines a new form of relationship between fathers and children. In some cases, the physical distance also means emotional distance, whereas in others, paradoxically, prison constitutes a favorable scenario for fathering (Granja, Cunha \& Machado, 2013; Secret, 2012), because being deprived of freedom can lead the father to rethink his life outside prison. Sérgio, when asked how he defines the experience of being a father, answered:

"In the past, when I was outside, I didn't care about that kind of thing, 'oh, I'm a dad, even though I was with my daughters, I didn't pay much attention to them [his daughters], only after we are away from them that we value it, I was always with them, but it was not the same thing [talking about how he saw fathering before and how he sees now]" (Sérgio).

This extract recounts a change in perception felt by this father regarding his daughters. He expresses that they are more relevant in his life now that he is incarcerated, which might be associated with the fact 
that male inmates rely on their families to help cope with the imprisonment. It becomes clear that maintaining family contact during the imprisonment experience eases the tensions inherent to the incarceration process, which include stress, frustration, sadness, and the need to deal with overcrowding and the precarious conditions of the institution. Family members act as a link between two worlds: outside and inside the prison. In other words, the family helps individuals deprived of the freedom to interact and connect with the outside world, allowing them to preserve, even if only slightly, some aspects of their identity and singularity (Hairston, 2003). This situation is particularly relevant for incarcerated fathers who can, using visits and regular contact with their families, reframe and rethink their role as a father.

In this study, with the exception of participants Lucas, Eduardo e Pedro, all fathers interviewed reported having some kind of contact with their children and, in general, expressed positive perceptions about fathering. Similar to the findings of Lee et al. (2012), where several male inmates reported keeping an intimate and close relationship with their children, actively participating in their upbringing, despite being incarcerated. When asked about what it is like to be a father while being in prison, Miguel answered:

"In reality, it's the same as it would be out there, the same thing that is out there, because if your child obeys you it doesn't matter if you're arrested, if you're in another place, if your child already has the mind-set to obey, you don't have to struggle much with that kind of thing, I don't struggle much with it, then being a father in here or out there in the street for me has been the same, get it? I love for my children and they love me, they respect me and I respect them, get it?" (Miguel)

The concept expressed by this father, that there are no significant differences between fathering inside or outside the prison can be interpreted in at least two ways. This father may deny the impact that his imprisonment has on his children's lives, as well as idealizing the relationship he has with his children. Some studies suggest that parents in prison build expectations regarding their behavior as a father, both during the period in which they are incarcerated and when they are released (Arditti, 2012).

On the other hand, Miguel's speech can also indicate that fathering within the prison context must be examined beyond the presence-absence dichotomy. In this study, many men reported, as did Fernando, Eduardo, Leonardo, Pedro and Sérgio, not having close contact with their children before being arrested, either due to abusive drug use, troubled relationships with former partners, or because they lived in different cities. Consequently, as absent fathers before reclusion, it is natural that these men would not perceive the estrangement caused by the deprivation of freedom any differently. Although the naturalization of the link between motherhood with the female gender is criticized by several currents of feminism (Brasil \& Costa, 2018), in the context of deprivation of liberty, mothers are usually the primary caregivers, being almost entirely responsible for childcare, even before the father's imprisonment (Granja, Cunha, \& Machado, 2013). For these men, the paternal figure represented by their authority should suffice, being able to replace their physical presence in the children's lives.

As mentioned before, some interviewees, such as Fernando, Eduardo, Leonardo, Pedro and Sérgio, reported being only modestly present in their children's life before incarceration, illustrating the fact that being free does not automatically mean they had a close relationship with their children. Indeed, the social and economic disadvantages that mark their lives make the concepts of presence, involvement, care, and material provision more dependent on contextual circumstances than on their desire to be good fathers (Granja, Cunha, \& Machado, 2013).

On the other hand, the fathers who were physically and/or emotionally close to their children reported seeking strategies to stay present while being in prison, as the speeches Thomas, Lucas, and Márcio will show. Considering this context where having physical contact with their children is not always possible, the use of correspondence was the most cited mean of staying in contact and being able to keep up with their lives, as illustrated in the subsequent speech by Thomas:

"Through letters. That's the only way, because of the presence... There's no way to be present out there, right? Then, through the letters. I try to explain my way to him, a little bit, to my son, in the letters, 
you know? This way, I try to put myself in his life. From a distance, it is only by letter. Pretty rough..." (Thomas).

Studies indicate that men deprived of their freedom use letters as a strategy to share experiences and fill the gap caused by their absence (Mapson, 2013; Miranda \& Granato, 2016). Although not legal, Lucas and Márcio also mentioned the use of video and voice calls on mobile phones to talk to their children:

"I would talk to him by video call, see the photograph, I would talk to his mother, she would show me pictures at the time, then delete them ..." (Lucas).

"Well, in reality ... You know that within the prison system you have ... most of the galleries have a phone, even my two-year-old grandson knows that. So we had a lot of contact over the phone, get it?" (Márcio).

Regarding the desire to want or not to receive the visit of the children we identified some ambivalence towards the children's visits, similar to the findings of Techera, Garibotto and Urreta (2012). While some mentioned that visitations were crucial for coping with the hardships imposed by incarceration, others argued that prison is not a suitable place for children. For those fathers, receiving their children's visits means extending the punishment for the crimes they committed to them. Similar to the findings of Miranda e Granato (2016), for some men, keeping their children away from the prison environment is a form of protection and care.

"First, I don't want it ... [upon being questioned if he is visited by his son] in the state that I am in... I am imprisoned, this is not a good place, it has never been a good place. I don't think anyone wants to see their son in here, in this bad place, the air is heavy ..." (Pedro).

"It's bad [not receiving visits from the children], but I think they will suffer more ... For them to come and me having to stay here when it's time to leave ... the gate separating us. Then I'd rather have it like this so I don't suffer ... So it doesn't hurt them and it doesn't hurt me either. It's just that I think, well, I did it, I made a mistake, I will pay for it, do you understand? ”(João).

It is interesting to highlight that the ambivalence about the children's presence in the prison environment permeated the speeches of all interviewees. Even those who stated they would like their children to visit also expressed concerns about the impact of being in contact with the prison environment. Similarly, those who expressed disapproval about visitations admitted missing and wishing their children were closer. It is worth mentioning that the discourses of some inmates that do not wish to be visited by their children because they feel they should endure punishment for their crimes alone can be considered a reproduction of a normalized and expected speech. In this context, fathers are expected to take full responsibility and shelter their children from potential harm or embarrassment caused by their conduct.

Concerning the explanations given to the children about their father's incarceration, concealment and denial were frequent (Techera, Garibotto, \& Urreta, 2012). The most common behavior was to tell the children that their father was away for work, instead of exposing the prison situation. However, many fathers admit it is not possible to sustain the made-up version very long. The following extracts exemplify this issue:

"That I was working [what he said to his son when he was arrested] and that one day his dad would come home when his dad finished the job, that I would come home ... When I caught him talking about police stuff, 'Dad's in jail', I saw that he couldn't be fooled, get it?" (Eduardo).

"Until when they were little, I tried to say that I was at work, but after they began to discern between things I told them the truth, it was useless because they could see the armed police, they often saw me in the hall over there, on one occasion they are coming in and you are going... like coming here, right, to talk to you" (Diego).

Consistent with other studies (Miranda \& Granato, 2016; Techera et al., 2012), we identified in the participants' discourses that the relationship between the incarcerated father and the children's mother is crucial for the contact between father and children to be maintained. Thus, a distant and conflicted relationship with the children's mother almost always implied in some kind of emotional separation 
between father and child, since the mother is responsible for bringing and/or authorizing the children to enter the correctional facility. One of the interviewees, answering to why he does not receive visits from two of his three children, explained:

"They used to visit before when I was with the mother of my children, the first two. Now they don't visit me anymore because she gets mad that I am having another child with another woman ... And she even refused to let my mother bring them, she does not want me to see the children" (Eduardo).

The previous extract introduces an interesting topic into the discussion, as it ascribes to the women - once again - the responsibility for safeguarding the family ties. That is, the mother is held responsible for the separation between father and child, while the father assumes a static and passive attitude towards the disruption of this contact. This situation indicates a representation of fatherhood where the father's involvement is considered peripheral and, in a sense, elective. Categorizing women as uncontrolled beings, who use their children as an instrument to punish their partner, is a discursive way for men to shy away from their responsibility for the kind of relationship they have built with their children's mother, as it divests themselves from the duty of having been a good father, of having established their place independent of the relationship with this woman.

\section{Criminality X Fatherhood}

This category addresses the issue of criminality and its relationship with fatherhood. In addition to discussing the fears and concerns that participants have about whether or not their children are involved in crime, it seeks to discuss the motivations for crime and expectations for life outside prison by the interviewed men.

Several studies showed that men deprived of their freedom feared that their children's frequent contact with the prison environment could enhance the risk of future involvement with crime (Miranda \& Granato, 2016; Silva \& Guzzo, 2007; Techera et al., 2012). Conversely, the majority of fathers interviewed in this study declared not having this concern. When asked whether they worried their children would become involved with crime, participants replied:

"No, if it's up to me, no. Because I was always present and that will not change. Wherever they go, I'll come along, if they must go somewhere, I'll take them, I'll pick them up ..." (Daniel).

"No, because by the time I leave here, I think I'll catch it, not think, I am going to catch him in his youth so I'll be there to give him some pointers, or if he doesn't learn for himself, but he's well educated, he'll learn, he's a quiet boy, even at school he does the things he is supposed to do, stays quiet in his place, so I think with him I won't have any concerns" (Lucas).

Daniel and Lucas, among others, understood criminalization as an individual issue motivated by a lack of education or exposure to bad examples. Thus, under the justification that their children were well educated, religious, and able to discern between right and wrong, the fathers stated they were not afraid their children would engage in criminal activities. The idea of the father's incarceration serving as a positive example to avoid children from engaging in crime appeared frequently in the analyzed discourses:

"No, I've always treated them this way, with a kind of pressure, but as I said giving a mind to their thoughts 'Have you seen what it's like in here?' I would take them to the cell, the gate, the courtyard, and show them those who'd stay just lying there in the courtyard with no visitors, I'd say 'this is what will happen to you, your dad got lucky, your mother is a warrior, helped me and such, but if you go to prison, your mother will only visit you if you stay in the same place in the same wing, otherwise you will go without a visitor', I have always worked with them in this way and advising them: 'This is no life, don't mirror yourselves in me, if you mirror yourself in me you will go the wrong way." (Diego).

The representation of fatherhood conveyed in Diego's discourse seems to agree with the concept of fatherhood largely associated with authority. The participant's paternal presence would take place even in his absence since he says alone - that is, his advice on what not to do - would be enough to direct his 
children's choices. Interestingly, in the previous extract, we can sense a certain contradiction in this father's discourse when advising the children not to commit crimes. While expressing concern about not being an example, since he is incarcerated, he also seems to want to serve as an example, when he mentions that the mother will only visit the children who get in trouble with justice if they go to the same place he is at an evangelical gallery.

According to França, Neto and Artuso (2016), the installation of evangelical churches inside prisons, spread the idea of the "good Christian folks" (p. 121). Because the evangelical wings are cleaner and more organized, with more rigid schedules and greater discipline control coming from the priests, the inmates present themselves and are often seen by the prison house, as model prisoners. It is important to mention, however, that not all the inmates inside this environment are actual devotees, but play, deceivingly, the believer role. Either way, one can speculate that the widespread idea of such wings being differentiated led the participant to praise the place where he fulfills his sentence, trying to present himself as a distinguished inmate, which is why he tells his children that their mother would only visit them in jail if they stayed in a similar place.

Knowingly, the motivation for delinquency is the result of several factors, including internal ones, such as motivation and personality features, but also external factors are facilitators for delinquent behaviour, such as the economic and social situation, and belonging to circles in which crime is naturalized (Techera, Garibotto, \& Urreta, 2012). However, we highlight that the criminality concept considered in this study is more linked to social and external factors than to personality. That is, we are working with an understanding of criminality as something socially produced.

Among this study's participants, criminality was remarkably viewed as a consequence of purely individual choices, not accompanied by criticisms on the social place they occupy, reproducing a hegemonic cultural discourse that speaks of criminality as personal deviance. Using the Brazilian prison population as a reference, who predominantly come from a less favored social class and deprived of welfare services and policies (Barcinski \& Cúnico, 2014), we understand the importance of setting the discussion into broader terms, fighting the idea of the poor being fundamentally prone to crime, and discussing the influence of a precarious State, unable to provide basic constitutional rights, on the increase of criminality. These issues are meant to minimize and problematize the alleged generational and familial aspects of criminality, responsible for considering the family - and especially the children - as an extension of the prisoner, capable of influencing the decision of committing criminal acts (Guimarães, Meneghel, \& Oliveira, 2006).

Equally recurrent in the interviews were the participants' statements about the desire to change their lives, to start over, and make new choices in the post-incarceration period. A discourse of redemption sustained, especially, by the desire to be around family and to live with their children.

"My first plan is that the change I had ... it was already my first plan, my change and my desire to change and get out and work. The first thing: get a job, since I have a profession on the outside and the drugs... as I explained to you, mam, it was the drugs that took me away from everything, from family and work (...) Have my big family again and I'll make it through, right? I won't give up, right? It's what I have, my family, no way around it" (Fernando)

Although the scientific literature emphasizes that family ties can, effectively, constitute a protective factor for non-recurrence (Lee et al., 2012, Mapson, 2013, Miranda \& Granato, 2016, Waldegrave \& Woodall, 2016), it is important to reflect on how much these "remission discourse" - i.e., the recurrent statements that they want to change their lives and that when they leave prison they will be honest workers - are influenced by the discourse of being a "good citizen", the one who works and loves/cares for his family.

Additionally, these are influenced by the process of institutionalization itself promoted by the prison, once the institution stresses and reinforces redemption discourses and the appreciation for domesticity, imposing a docility-utility association on the inmate (Foucault, 1975/2004). 
According to the LEP (1984), the State must treat and reintegrate individuals deprived of their freedom back into society. However, Barcinski e Cúnico (2014) and Brasil (2017) emphasize the implicit conception that the responsibility for resocialization rests exclusively with the offender. He must make changes in both values and conducts to be able to re-enter society. Thus, the resocialization process would be contingent on repentance for the crimes and felonies committed, and on the genuine personal desire for change, which could altogether motivate the transformation and redemption discourses coming from the individuals deprived of freedom.

In this context, fatherhood and the image of the "good father" can be used as a resource for fathers who are imprisoned, similar to what happens to women, as a form of resistance against the unwanted "prisoner" status (Ugerlvik, 2014). Particularly in this study, the enactment of the good prisoner role was recurrent, as if this performance - within the interview environment to which the fathers were subjected could bring some subsequent benefit with the prison authorities. One of the participants, however, when reflecting about his actual possibilities of change upon regaining freedom, mentioned:

"But I have to do something for me to survive, I'll try to work, I'll try, if I can't, well ... That's what I know how to do, right? [Stealing] If I feel bad and I see that we will be short of food, I'm going to ... we'll be short of clothes, ... we'll be short of diapers, I'll make it even. I will steal. The thing is, some have too much, others have less" (Leonardo).

The previous discourse presents a clear social critique, and refers to a conception of recidivism not defined as a mere individual choice, but as a product of the social control circumstances themselves, which are extremely selective and prejudiced. Imprisonment should be considered as a last resort, not a customary measure (Techera, Garibotto, \& Urreta, 2012). Far from doing justice or preventing criminality, imprisonment not only enhances deviance, as it consolidates the offender stigma, making it harder to reintegrate the former inmate back into the community (França, Neto, \& Artuso, 2016). Given this, the experience of having passed through the prison system could be described as a stigma that never fades, even after the release (Arditti, Smock \& Parkman, 2005).

According to Foucault (1975/2004), even if we acknowledge the precariousness and failure of prison in its re-socializing goal, it is undeniable that its maintenance fuels and consolidates the crime world in contrast to the good citizens. This duality serves as an alibi for supporting and increasing police repression and keeps the system working as it renders acceptable judicial control and surveillance on society.

\section{Final considerations}

This study aimed to analyze the meanings attributed to fathering practices by imprisoned men and the practices themselves. By the results and discussion shown, it was clear that the fathering practices and the way the interviewees see themselves as fathers were not unanimous or homogeneous, confirming that fathering is complex and is lived by each man in a very particular way, being influenced by various markers. Especially within the incarceration context, we cannot assume that fatherhood would have a central role in these men's identities since we need to consider that - in contexts that diverge from a traditional family and fathering models - the experience of being a father may take on multiple and differentiated meanings.

Overall, the fathers interviewed in this study described a positive and encouraging fathering experience. Contrary to a more traditional view, where the father is primarily the breadwinner, the interviewees' discourses revealed other dimensions in the ways they experience fathering, based on a concept that goes beyond the presence/absence dichotomy.

Moreover, being imprisoned allows this view of the father - as essentially the breadwinner - to be reconfigured and re-signified through their trajectories and novel possibilities of connection with their children. This is because, among the scarce options available for men deprived of their freedom to preserve 
their father role within the prison environment, affective and emotional efforts can become fundamental, resignifying their previous experiences.

It is worth mentioning that fatherhood is a construction that can take on multiple meanings in man's life. Therefore, it is not possible to talk about a unique model of being a father, given the plurality of ways of experiencing fatherhood that are crossed by markers such as race, social class, father's age, and transgenerational aspects. Assuming that fatherhood is built on several levels is, based on this understanding, a way to prevent essentialist and reductionist interpretations.

By analyzing the discourses presented in this study, we presume that the father's peripheral role is legitimized and consolidated when histories of separation and estrangement already existed, even before the father was imprisoned. Undeniably, the Brazilian correctional facilities, overall, do not present reasonable conditions to properly and safely welcome the children. As mentioned before, all visits occur inside the cells and galleries, without any supervision of the guards. Most of all correctional facilities in Brazil are overcrowded and the number of prisoners far outnumbers the guards. It is then impossible for them to stay together during visitation, leaving visitors and prisoners by themselves.

However, we argue that the lack of State's investment and the precariousness of government actions concerning the prison system should not pose an obstacle for preserving the inmate's contact with family members. In other words, the prison, as an institution carrying the duty to protect its inmates' integrity, should not undervalue the social and relational dimensions of the father role, once the punishment for breaking the law should not be extended to children through the total interruption of contact with their fathers. Furthermore, from a gender perspective, it would be important to foster caregiving actions and restructure affective relationships on a more egalitarian basis.

As already mentioned, studies that deal with incarcerated parenting tend to focus more on aspects related to the relationship between the incarcerated mother and her offspring. Studies dealing with paternity in this context, especially in Brazil, are not common. The results presented here, however, demonstrate that paternity in the prison is also a complex phenomenon and that it should be a focus of academic problematization. Its relevance is given both in the context of gender studies and in the studies involving the family and different settings. It is understood, then, that this qualitative research opens venues for new research with incarcerated fathers in focus.

Despite these findings and implications, there are some limitations to the current study. It is important to recall that all inmates were chosen by the facility administration, which certainly influenced the results. Also, being interviewed by a female researcher could have influenced the results. The stereotype associated with the woman as a caregiver may have influenced the participants to report parental practices from a tenderer and behaved fashion, unlike what would possibly happen if the interviewer were a man.

Naturally, the results of the research reported here are limited to a certain reality of the prison in which the investigation was made. This research was conducted in a specific period, an investigation that is traversed by gender; thus, results do not apply to all contexts and may vary from context to context. This matter does not diminish the results of the study since qualitative research does not intend to generalize.

\section{References}

Andersen, M. \& Collins, P. H. (2007). Why race, class, and gender still matter. In M. L. Andersen, \& P. H. Collins (Eds.), Race, class, \& gender: an anthology (pp. 1-16). EUA: Thomson Wadsworth.

Arditti, J.A. (2012). Parental incarceration and the family: psychological and social effects of imprisonment on children, parents, and caregivers. New York and London: New York University Press.

Arditti, J. A., Smock, S. A., \& Parkman, T. S. (2005). "It's been hard to be a father": a qualitative exploration of incarcerated fatherhood. Fathering, 3(3), 267-288. 
Barcinski, M., \& Cúnico, S. D. (2014). Os efeitos (in)visibilizadores do cárcere: as contradições do sistema prisional. Psicologia Portugal, 28(2), 63-70.

Bornholdt, E. A.; Wagner, A., \& Staudt, A.C.P. (2007). A vivência da gravidez do primeiro filho à luz da perspectiva paterna. Psicologia Clínica, 19(1), 75-92. doi: http://dx.doi.org/10.1590/S0103-56652007000100006

Brasil. (1984). Lei de Execução Penal. Available at: http://www.planalto.gov.br/ccivil_03/leis/17210.htm. Accessed in: 10 June 2014.

Brasil. (2014). Lei ${ }^{\circ} 12.962$, de 08 de abril de 2014. Altera a Lei $n^{\circ}$ 8.069, de 13 de julho de 1990 - Estatuto da Criança e do Adolescente, para assegurar a convivência da criança e do adolescente com os pais privados de liberdade. Available at: http://www.planalto.gov.br/ccivil_03/_Ato2011-2014/2014/Lei/L12962.htm. Accessed in: 25 June 2014.

Brasil. (2017). Levantamento Nacional de Informações Penitenciárias - Infopen. Departamento Penitenciário Nacional - Ministério da Justiça, 2017. Available at: http://www.justica.gov.br/news/ha-726-712-pessoas-presas-nobrasil/relatorio_2016_junho.pdf. Accessed in: December 8, 2017.

Brasil, M. V., \& Costa, A. B. (2018). Psicanálise, feminismo e os caminhos para a maternidade: diálogos possíveis? Psicologia Clínica, 30(3), 427-446. doi: 10.590/19805438300320180427

Cisneros-Puebla, C. A., Faux, R., \& Mey, G. (2004). Qualitative Researchers-Stories Told, Stories Shared: The Storied Nature of Qualitative Research. An Introduction to the Special Issue: FQS Interviews I. Forum Qualitative Sozialforschung / Forum: Qualitative Social Research, 5(3). doi: 10.17169/fqs-5.3.547.

Cúnico, S.D., Quaini, R.P., \& Strey, M.N. (2017). Paternidades encarceradas: revisão sistemática sobre a paternidade no contexto do cárcere. Psicologia \& Sociedade, 29, 1-11. doi: $10.1590 / 1807-0310 / 2017 \mathrm{v} 29168770$.

Fonseca, K.P. da (2006). Re(pensando) o crime como uma relação de antagonismo entre seus autores e a sociedade. Psicologia: ciência e profissão, 26(4), 532-547.doi: 10.1590/S141498932006000400002.

Foucault, M. (2004). Vigiar e Punir: Nascimento da prisão (20 Ed.) (R. Ramalhete, Trad.). Petrópolis, RJ: Vozes. (Original publicado em 1975).

França, L. A., Neto, A. S., \& Artuso, A.R. (2016). As marcas do cárcere. Curitiba: iEa Sociedade.

Granja, Rafaela, Cunha, Manuela P. da, \& Machado, Helena (2013). Formas alternativas do exercício da parentalidade: paternidade e maternidade em contexto prisional. Ex аеquо, 28, 73-86.

Guimarães, C.F., Meneghel, S.N., \& Oliveira, C.S. (2006). Subjetividade e estratégias de resistência na prisão. Psicologia Ciência e Profissão, 26(4), 632-645.

Hairston, C. F. (2003). Prisoners and their families: parenting issues during incarceration. In J. Travis., \& M. Waul (Eds.). Prisoners once removed: the impact of incarceration and reentry on children, families and communities (pp. 259-282). Washington, DC: Urban Institute Press.

Jarvis, Joy, Graham, Sally, Hamilton, Penny, \& Tyler, Dena (2004). The role of parenting classes for young fathers in prison: a case study. Probation Journal, 51(1), 21-33.

Lee, Ch-B., Sansone, F.A., Swanson, Ch., \& Tatum, K.M. (2012). Incarcerated fathers and parenting: Importance of the relationship with their children. Social work in public health, 27, 165-186.

Machado, H., \& Granja, R.P.G. (2013). Paternidades fragmentadas. Género, emoções e (des)conexões biogenéticas e prisionais. Análise Social, 48(3), 550-571.

Mapson, A. (2013). From Prison to Parenting. Journal of Human Behavior in the Social Environment, 23(2), 171-177. 
Miranda, M.L.A., \& Granato, T.M.M. (2016). Pais encarcerados: narrativas de presos sobre a experiência da paternidade na prisão. Psico, 47(4), 309-318.

Poupart, J. (2008). A entrevista do tipo qualitativo: considerações epistemológicas, teóricas e metodológicas. In Poupart, Jean, Deslauriers, Jean-Pierre, Groulx, Lionei-H, Lapierre, Anne, Mayer, Robert, \& Pires, Álvaro. (Eds.). A pesquisa qualitativa: Enfoques epistemológicos e metodológicos. (A. C. Nasser, Trad.) (pp. 215-253). Petrópolis, RJ: Vozes.

Secret, M. (2012). Incarcerated fathers: exploring the dimensions and prevalence of parenting capacity of non-violent offenders. Fathering, 10(2), 159-177.

Silva, M.F., \& Guzzo, R.S.L. (2007). Presidiários: percepções e sentimentos acerca de sua condição paterna. Revista Brasileira de Crescimento e Desenvolvimento Humano, 17(3), 4859.

Superintendência dos Serviços Penitenciários. (2017). Relatório Estatístico. Available at: http://www.susepe.rs.gov.br. Acess in: 10 November 2017.

Tavares, G.M., \& Menandro, P.R.M. (2004). Atestado de exclusão com firma reconhecida: o sofrimento do presidiário brasileiro. Psicologia: Ciência e Profissão, 24(2), 86-99.

Techera, J., Garibotto, G., \& Urreta, A. (2012). Los "hijos de los presos": vínculo afectivo entre padres privados de liberdad y sus hijos/as. Avances de un estudio exploratorio. Ciencias Psicológicas, 6(1), 57-74.

Ugelvik, T. (2014). Paternal pains of imprisonment: Incarcerated fathers, ethnic minority masculinity and resistance narratives. Punishment \& Society, 16(2), 152-168.

Van Dijk, T.A. (2008). Discurso e poder. São Paulo: Contexto.

Waldegrave, K.E., \& Woodall, J. (2016). A father in prison is still a father: paternal imprisionment and infant mental health. Journal of health visiting, 4(6), 1-4.

Funding: This project was financed through a phd scholarship by CAPES (Coordination for the Improvement of Higher Education Personnel).

Author's participation: a) Conception and design of the work; b) Data acquisition; c) Analysis and interpretation of data; d) Writing of the manuscript; e) Critical review of the manuscript.

S.D.C. has contributed in a, b, c, d, e; M.N.S. in a,c; A.B.C. in c,e.

Scientific Editor in charge: Dra. Cecilia Cracco 